\title{
Access and Property: A Question of Power and Authority
}

\section{Thomas Sikor and Christian Lund}

\section{INTRODUCTION: THE ARGUMENT}

As larger political economic forces transform rural resources of material or cultural value, access to these resources is often contested and rife with conflict at many levels simultaneously. In societies characterized by normative and legal pluralism such as post-colonial and post-socialist countries, this is particularly evident. The central dynamic is created by people's attempts to secure rights to natural resources by having their access claims recognized as legitimate property by a politico-legal institution. The process of recognition of claims as property simultaneously works to imbue the institution that provides such recognition with the recognition of its authority to do so. This is the 'contract' that links property and authority. Property is only property if socially legitimate institutions sanction it, and politico-legal institutions are only effectively legitimized if their interpretation of social norms (in this case property rights) is heeded (Lund, 2002). The process of seeking authorization for property claims also works to authorize the authorizers and, at the same time, institutions underpinning various claims of access hence catering for particular constituencies - undermine rival claims to the same resources.

Nevertheless, property is part of a larger picture of access to resources, whether legally recognized or not. While not all forms of access to resources or their benefits are guaranteed by a politico-legal institution, they may still constitute an important element in people's livelihoods. Indeed, the 'grey zone' between what people have rights to and what they merely have access to is terrain worth exploring. In parallel to this, politico-legal authority is only part of a larger picture of power, whether legitimate or not. Not all forms of power to decide who gets access to what resources and benefits, and on what terms, are legitimized with equal effect. Nonetheless, powerful groups and institutional coalitions may still exercise what are essentially political decisions about people's access to resources and benefits. This second 'grey zone' between authority and power — that is, successfully and

The chapters in this volume originate from a researcher training workshop jointly organized by the Junior Research Group on Postsocialist Land Relations, Humboldt University Berlin, and the Graduate School of International Development Studies, Roskilde University, in late 2006. Funding for the workshop was provided by Deutsche Forschungsgemeinschaft and Roskilde University. We thank Sara Berry, Anne Larson and three anonymous reviewers for their constructive comments on this introductory essay. This essay has also benefited from very stimulating discussions with the workshop participants and contributors to this volume. 
less-successfully legitimized decisions about how resources are distributed in society - is equally worth investigating. These two sets of relationships, their interconnections and recursive constitution form the object of this chapter.

Two issues are therefore simultaneously at stake: struggles over property are as much about the scope and constitution of authority as about access to resources. To investigate how competition for society's vital resources is organized and structured is to investigate not only how wealth is distributed and how classes of 'haves' and 'have-nots' are made; it is equally to investigate how polities emerge, consolidate and recede through processes of legitimization, inclusion, exclusion and violence. The social, political and institutional landscape is amorphous at close inspection, however (Cleaver, 2002; Douglas, 1986). Nuijten uses a very suggestive conceptualization of a force field to refer to a wider set of diverse powers: 'In a force field certain forms of dominance, contention and resistance may develop, as well as certain regularities and forms of ordering. In this view, the patterning of organizing practices is not the result of a common understanding or normative agreement, but the forces at play within the field' (Nuijten, 2003: 12). Our argument is that within such a force field, organizing practices that concern the distribution of resources are particularly interesting.

This introduction and the chapters that follow in this collection venture to make a particular incision into the recursive constitution of property and institutional authority. By investigating both successful and failed processes of legitimation of access as property, and processes of legitimation of power as authority, we develop a novel interpretation of the distinction between access and property. We argue that issues of access and property are joined to questions of power and authority. People attempt to consolidate their claims to land and other resources in various ways, often in pursuit of turning their access to resources into recognized property. In our argument we bring together two perspectives on resource use that often remain separated, and which have produced two strands in the literature - one on broader accesspower relations (such as Berry, 1993; Ribot and Peluso, 2003) and another on the narrower property-authority relations (including Lund, 2002, 2007). In the process, we hope to clear up some of the dynamics generating the ambiguity of property observed in post-colonial and post-socialist settings (cf. Berry, 1993; Verdery, 1996).

Moreover, by investigating how institutional authority and property rights are recursively constituted, we are also investigating governance and state formation processes. The political dynamics of property are the processes whereby rights over land and other natural resources are settled and contested. They are fundamental to how authority is established and challenged among competing politico-legal institutions, thereby allowing the study of property dynamics to facilitate special insights into everyday processes of state formation. The institutional contestants' pursuit of control over natural resources involves them, unavoidably, in the competition for authority, its 
consolidation, reconfiguration and erosion. This is not necessarily done with the intention of state formation at the local level; it is done to check and overcome their competitors and benefit from the advantages of power. The result is nonetheless, in part, institutional (see Lund, 2008: 3; Tilly, 1985). Recent years have seen the emergence of a rich literature on state formation in post-colonial contexts. ${ }^{1}$ Characteristic of this - admittedly very diverse - work is an interest in the almost forensic analysis of political processes that make up state, legitimacy and authority. The key word is process.

This introductory essay seeks to position our argument in relation to the literature and the contributions to this volume. Considering the wealth of research in the two fields, the discussion of the literature is necessarily somewhat eclectic and may appear overly simplistic at times. Yet we intend to sketch out the contours of the larger, theoretical argument pursued in the chapters that follow. The essay begins by discussing the difference between access and property and subsequently looks at legitimacy and legitimizing practices. We then proceed to establish the mutually-constitutive character of property and authority, as legitimacy travels back and forth between the two. As a next step, we look into the dynamics of power and authority to examine the role of property in the making and unmaking of authority. We then return to our interest in the dynamics of access and property, on the one hand, and power and authority, on the other, identifying territoriality as a particularly interesting notion and examining the use of violence in institutions' legitimizing practices. We finish with syntheses of the chapters in this volume, relating them to the discussion in this introductory essay, and some brief concluding remarks.

\section{PROPERTY AND ACCESS: A PARTIAL OVERLAP}

Most simply put, property is about relationships among social actors with regard to objects of value (von Benda-Beckmann et al., 2006). Property relations involve different kinds of social actors, including individuals and collectivities. The actors are linked to each other in social relationships, and property takes the form of 'enforceable claim[s] to some use or benefit of something' (MacPherson, 1978: 3). Property relations exist at the level of laws and regulations, cultural norms and social values, actual social relationships, and property practices. Property is therefore legitimized claims, in the sense that the state or some other form of politico-legal authority sanctions them.

1. The list is long, but includes Boone (2003); Comaroff and Comaroff (1999); Corbridge et al. (2005); Das and Poole (2004); Gupta and Ferguson (1997); Hansen and Stepputat (2001, 2005); Lund (2007); Migdal (2001); Nuijten (2003); Sivaramakrishnan (1999); Steinmetz (1999); Sturgeon (2005). 
Property relations in post-colonial and post-socialist settings are often ambiguous. In post-colonial contexts, property regimes are negotiable and fluid to some degree because of the multiplicity of institutions competing to sanction and validate (competing) claims in attempts to gain authority for themselves (von Benda-Beckmann and von Benda-Beckmann, 1999; Berry, 1993, 2002; Juul and Lund, 2002; Moore, 1998; Shipton and Goheen, 1992). This frequently provides scope for accumulation for the powerful (Peters, 2004). Post-socialist property relations are often equally equivocal as social actors struggle over the very categories and relationships constituting property (Sturgeon and Sikor, 2004; Verdery, 1999).

The utility of property as an analytical lens has been challenged as too narrow by recent emphasis on the multiple mechanisms that open up, influence, hinder and close down access to resources. Property is not the only way by which social actors are able to benefit from resources. Access, by contrast, is broader and includes property. Law or other social norms do not sanction and encompass all forms of possession: it is equally important that social actors gain and maintain access to resources in many ways that do not amount to property (Leach et al., 1999; Ribot and Peluso, 2003). A variety of access mechanisms condition people's access to resources and benefits. In addition to property, these include technology, capital, markets, labour, knowledge, identities and social relations (Ribot and Peluso, 2003: 159-60). The difference between access and property implies that social actors may derive benefits from resources without holding property rights to them. For example, they may derive benefits from an agricultural field - by way of occupation or market exchange - even though they do not hold any rights to the land. It is important, therefore, to 'understand why some people or institutions benefit from resources, whether or not they have institutionally recognized rights to them' (Ribot and Peluso, 2003: 154; emphases in the original). Access is thus different from property, as access is about 'the ability to benefit from things' (Ribot and Peluso, 2003: 153), making it more encompassing than property, which refers to legitimate social relationships only.

Ribot (1998) provides an illustrative example of the many ways by which social actors enjoy access to resources. He investigates the distribution of benefits along a charcoal commodity chain in Senegal from extraction in the Tambacounda region, through processing, transport, and trade to final use in Dakar. On the way to the capital city, the charcoal passes through the hands of various actors, including villagers, migrant woodcutters, merchants, transporters, urban wholesalers, retail vendors and outlet owners. They are all able to benefit from the charcoal commodity chain, yet they derive their respective benefits in different arenas and by way of different mechanisms. Villagers, for example, enjoy customary property rights to forests, even though Senegal's forests are legally owned by the state and managed by the Forest Service. In contrast, migrant woodcutters derive benefits from charcoal not through direct rights to the forests but by seeking employment with 
charcoal merchants. They gain these labour opportunities by way of a shared social identity and social ties with the merchants, the stigma attached to the work, and specialized technical skills. Merchants, in turn, reap a significant share of overall benefits, due to their control over labour opportunities and marketing. They work through 'social ties with other merchants, distributors, retailers and state agents, and through credit, misinformation, licenses, quotas and circulation permits' (Ribot, 1998: 328). This analysis demonstrates that multiple mechanisms influence the distribution of benefits from natural resources among social actors. Property is only one of them, in addition to product markets, the institutions governing capital flows, technology, and so forth.

Correspondingly, formal property rights do not necessarily imply that the social actors holding them are able to derive material benefits from the natural resources to which those rights apply. This is very apparent, for example, in local dynamics associated with forest devolution in Vietnam's Central Highlands (Sikor and Nguyen, 2007). Here, the forest department decided to grant villagers use rights to local forests in an effort to improve forest protection and raise living standards. The department and the villagers settled on a relatively egalitarian distribution of property rights among the households belonging to indigenous ethnic groups. Nevertheless, the actual material benefits derived by local households displayed significant variation three years after devolution. The fields that the households had been able to clear in the forests varied in size and harvests, reflecting the influence of differences in the households' labour capacity and wealth. Similarly, households extracted different quantities of poles from the forests, and these differences were due to yet other access mechanisms. Better-off households extracted more poles because they owned the required machinery (chainsaws and tractors), were able to hire additional labour, and simply needed larger quantities of poles in their pepper plantations. Despite the devolution of forest management, access to the forest thus depended on a variety of access mechanisms in addition to property rights. For families who did not benefit from such mechanisms, 'property rights' remained effectively vacuous claims.

This situation is not uncommon; people may hold property rights to some resources without having the capacity to derive any material benefit from them. Cousins (1997) argues that people lack 'real' rights if such rights are promised in law but denied in practice. Verdery (2003) observes a lack of 'effective ownership' by Romanian villagers who find themselves unable to benefit from their land rights. This is exactly what the distinction between property and access is about: property is about claims which are considered legitimate, and access is about the 'ability to benefit'. It demonstrates that property and access overlap partially: property rights may or may not translate into 'ability to benefit'; and access may or may not come about as a consequence of property rights. But 'ineffective' ownership or property rights are distinct from no rights at all, even if they do not translate into ability to benefit. While rights may have no value at a certain point in time, 
the fact that they are somehow enshrined in legislation or recognized by some politico-legal institution may come in handy if circumstances change. Then it may actually be of great benefit to be able to refer to (historical) rights when vindicating claims (see Lund, 2008; Moore, 1992).

Thus, different processes may be at work simultaneously, leading to variations in social actors' property rights and access. The processes constituting property may be different from those leading to variation in access. Property relations may reflect the influence of a set of laws and norms lending legitimacy to claims on resources. Access, in turn, may be constituted by a different set of processes conditioned by a broader range of social institutions. As a result, property and access may be distributed among social actors in different ways. Going a step further, competition over access can in many ways be seen as the forerunner of property contestations where people try to secure their possession with recognition from a politico-legal institution. This calls for research into the economic, political and discursive practices that actors undertake in a terrain of competing claims when they seek legitimacy for their own (see Broegaard, this volume). Moreover, it suggests the need to investigate the processes whereby property is made and solidified or challenged and, possibly, undone, directing our attention to social practices employed by actors and institutions seeking to legitimize their actions.

\section{LEGITIMACY AND LEGITIMIZING PRACTICES}

Legitimization by a politico-legal authority emerges as the distinguishing factor between access and property. Obviously, legitimacy is not a fixed and finite substance: it is a result of processes of legitimization, some with distinct authorship, others as reproduction of mores; some successful, others less so. The point is that competing actors and competing institutions operate to legitimize different forms of possession as property. Hence, different, competing legitimacies are at play in situations of legal and institutional pluralism. The exercise of authority is intimately linked to claims of legitimacy of the particular institution. This often involves a general, historically-based claim as well as a specific claim to legitimacy. Institutions tend to argue or justify their legitimacy in relation to the concrete exercise of authority. But institutions do not embody intrinsic legitimacy; their legitimacy must be actively established.

This notion of legitimacy draws on work by both Moore (1988) and Lentz (1998), who argue that it is not useful to see legitimacy as a fixed, absolute quality against which actual conduct can be measured. It is more fruitful to investigate the processes through which various actors and institutions attempt to legitimize actions and vindications (Fortmann, 1995; Rocheleau and Ross, 1995). What is legitimate varies between and within cultures and over time, and is continuously (re-)established through conflict and negotiation. 
This notion of legitimacy also connects us with broader work on legitimizing practices, or 'grounded practices of sovereignty' (Moore, 2005). An important element in this process has to do with social conceptualization; that is, how concepts and 'truths' are established (cf. Agrawal, 2005; Ferguson and Gupta, 2002; Foucault, 1980; Li, 2007). These broader conceptualizations indicate to us that concepts and ideas about property and access are not merely the tools of the analysts. People and institutions actively employ and interpret concepts in their attempts to enact different political projects and interests. Concepts and ideas of different origin thereby enter local arenas and become 'idiomatized'. They are not merely instruments of analysis but are also their object. Thus, in addition to competition over land claims and claims to authority, conflicts also engender an ongoing (re)definition of the very concepts of property we might otherwise tend to see as fixed (Shipton and Goheen, 1992; Verdery, 2003).

It is quite clear that what is considered legitimate property is historically contingent. Although arguments often involve reference to precedent and the past, the right moment for pressing a particular claim depends on the contemporary political constellation of institutions that can recognize claims as valid. What constitutes a good claim at one moment may be less viable at another and may not resonate with what is generally or politically accepted. Similarly, what is perceived as legal or as illegal may change over time without any change in legislation. Government policies, statements and practices can effectively outlaw certain legal practices and nullify established rights. Government may thus effectively turn private property into public land, and the inventive opportunism of farmers may secure them private rights to public infrastructure, contrary to the legislation in place (see Lund, 2008 and this volume).

Local resource politics displays many instances in which the meaning of key terms such as public, private, government, legitimacy, ownership, etc. are effectively questioned. When policy is resisted, embraced, or diverted, such concepts become central reference points in the political debate. They appear stable, but in the larger claims for a livelihood and a position in life, people struggle over the local, idiomatic meaning of these concepts. Rather than regretting the inadequacy of the terms in describing the real situation, it is important to see these ideal concepts as integral parts of the political struggle. When, for example, various forms of indigenous land tenure are being translated into one-dimensional ownership in such discussions and debates, it bespeaks a deliberate simplification of a complex composite tenure system. The chapters throughout this volume demonstrate the importance of having a command over the terminology and the process of categorization.

Legitimacy and legitimizing practices, therefore, emerge as a defining element of property. Yet we want to go a step further. We want to use the distinction between access and property as an entry point into the processes constituting authority. We want to ask why and how some actors benefit 
from resources by way of property and others do not. What practices and processes allow some actors to get their claims to resources recognized as property rights, while other actors gain and maintain access through other mechanisms? More generally, what are the processes setting property apart from access?

\section{PROPERTY AND AUTHORITY: A CONTRACT}

As a first step, we propose to recognize that property not only sets up an economic relationship, in the sense that property relations influence the shares of social actors in benefit streams originating from resources; property relations are also political (MacPherson, 1978). In this sense, property rights have something in common with citizen rights as two fundamental aspects of social life: what we have and what we are - avoir and être. Property rights and citizen rights in their broadest form exist only to the extent that they are produced, endorsed and sanctioned by some form of legitimate authority (see the contributions by Berry, Nuijten and Lorenzo, and Peluso in this volume).

Property is intimately connected with authority, in the sense of legitimate (or rather successfully legitimized) power (Weber, 1976). In other words, authority refers to an instance of power that is associated with at least a minimum of voluntary compliance, making it likely 'that a command with a specific content will be obeyed by a given group of persons' (ibid.: 28). Authority characterizes the capacity of politico-legal institutions, such as states and their constituent institutions, village communities, religious groupings and other organizations, to influence other social actors. Authority thus relates to property because rights, privileges, duties, obligations, etc. require support by politico-legal authority (von Benda-Beckmann, 1995). Similarly, taxes and tributes are significant ways in which institutional recognition of people's claims to property is established and institutions are recognized by fiscal subjects. As authority grants or denies legitimacy to property claims, such claims are intimately bound up with the scope and constitution of authority. The two form a contract of mutual recognition. In situations of institutional pluralism so characteristic of post-colonial and post-socialist societies, however, political authority is not exclusively vested in the state, and moreover, the state is hardly a set of congruent institutions. This complicates the situation significantly, and many competing contracts are formed (Lund, 2006).

The intimate connection between property and authority becomes very apparent when authority relations are overlapping or change over time. For example, pre-colonial property rights in Java were largely determined by local communities connected to local kings in patronage relations (Peluso, 1992). Rural people acquired resources, such as land and trees, through their membership of a local community or, if they migrated, allocation by 
the local king. Under colonial rule beginning in the nineteenth century, the Dutch introduced a forest service that divided forest land from agricultural land and established a bureaucracy to manage forest land. Yet even then, there were multiple claimants to the forest: 'Local people, regional rulers, and entrepreneurs were engaged in a "layered" system of rights to control or use the forest and its products' (Peluso, 1992: 48). Over time, state control of the forest and forest land increased gradually, as laws eradicated the 'layered' system in 1870, and foresters planted teak in villages and restricted local access in the 1930s. With independence the Indonesian government simply took over the forest service, enforcing control over forest land in ways that were much more militarized and repressive than under Dutch rule. In response, forest-dependent villagers resisted state control either through everyday forms of resistance or outright violence. Yet they did not merely resist state control over labour, land and trees; they also countered the state's ideology of scientific forestry with moralities emphasizing subsistence needs and historical claims on forests. In this way, villagers asserted authority relations rooted in local communities that justified their own claims on forests and challenged the legitimacy of the state's claims (for a case in irrigation see also Roth, this volume).

In Africa there are many examples of how rights to resources have changed because of the changing status of the local authority which grants and guarantees rights. The waxing and waning of chieftaincy power in many societies have solidified or undermined property rights accordingly. Burkina Faso is an interesting example. The socialist-inspired revolution in 1983 did away with the chieftaincy as a political institution and all land was declared state property in 1984 . This led to considerable uncertainty about who was entitled to what and with whose authority. Because of central government's limited capacity to conduct, or even oversee, land transactions, these continued in some places under the authority of chiefs, and in others under the auspices of the new local political elite as 'land authorities'. In fact, some members of the emerging elite established their roles by actually distributing land and overseeing land transactions. This way, control over land did not represent customary authority; it produced it. Current legislation remains basically the same as that of 1984; nonetheless, as the chieftaincy was gradually rehabilitated as a political institution during the 1990s, some chiefs worked to recover some of their control over land, while others who had control over land worked to become chiefs (Lund, 2002). The general resurgence of chieftaincy as an integrated element of the governance structure in Africa will, no doubt, have serious implications for property rights on the continent in future.

The preceding paragraphs demonstrate how property and authority are closely linked. Property relates to authority because property claims require support by politico-legal institutions in a position of authority. When authority relations overlap, social actors are likely to reference their property claims to various politico-legal institutions, making property relations appear 
ambiguous to outsiders (Berry, 1993). Ambiguous authority, whatever the reason, thus attaches itself to the rights themselves and renders them less than clear. The ambiguity is compounded when social actors make claims in settings characterized by more fluid relations of authority and power, settings in which multiple politico-legal institutions compete over authority. The ensuing dynamic fluidity is the subject of the following section.

\section{DYNAMICS OF POWER AND AUTHORITY}

When authority and power relations are contested, politico-legal institutions tend to compete for authority. They not only struggle to acquire power to influence others, by whatever means (Weber, 1976); they seek to turn power into authority by gaining and sustaining legitimacy in the eyes of their constituency. Simply put, claimants seek out socio-political institutions to authorize their claims, and socio-political institutions look for claims to authorize. The relationship is a dynamic one, as illustrated by Keebet von Benda-Beckmann's notion of 'forum shopping' and 'shopping forums' (von Benda-Beckmann, 1981). In the presence of competing forums for resolving disputes, contestants tend to 'shop' for forums for dispute resolution, and forums actively shop for disputes in an effort to consolidate their authority. Such competition can unfold in many different fields, such as citizenship/belonging, personal security, development and property. Property is, we would argue, one of the most important fields in which politico-legal institutions seem persistently to compete for authority in post-colonial and post-socialist societies (Berry, 2002; Lund, 2002, 2006; Verdery, 1996). The institutions seek out property claims to authorize in their attempt to build and solidify their legitimacy in relation to competitors. An institution's success in this venture is hardly carved in stone, however; once-legitimate institutions may yield this space to other (new or old) institutions more adept at legitimizing themselves, sometimes with consequences for the very forms of property.

In northern Ghana the divestiture of land from the government in 1979 stirred up a hornets' nest of questions about authority. Land was 'returned to its original owners'. Legislators expected chiefs to re-establish themselves as the customary authority in land matters as in the rest of Ghana, where they have comprehensive customary authority in matters of land and law, and chiefs saw land as an important domain through which to consolidate their customary authority. Neither had factored in a possible re-emergence of the earthpriests as ambitious customary authorities. The earthpriests did not claim authority in general, but restricted themselves to questions of land. The new legal situation provided an opportunity for reassessing the past, resettling old accounts, reasserting 'belonging' in terms of prerogatives and jurisdictions, and renegotiating ownership to land. Chiefs and earthpriests intensified their competition over control of the land. The justification of 
claims to authority was played out in different fashions and forms. In the town of Bolgatanga, earthpriests formed a union to better stand up to the chiefs, who were well organized historically and represented in local governance bodies such as the House of Chiefs. Lobbying with, among others, the Lands Commission over the right to issue land leases and with the Electoral Commission over administrative boundaries, and fighting cases in the High Court over compensation for loss of property, chiefs and earthpriests were struggling to assert their authority to handle land matters. One interesting feature of this process is that not only did chiefs and earthpriests operate as institutions (or 'forums') to grant, sanction and guarantee the property claims of ordinary land users, they themselves shopped around for opportunities to prove their capacity as authorities. Moreover, these aspiring authorities also sought out the endorsement of their claim to authority with other institutions (in particular government institutions) such as the Land Commission, the Electoral Commission, and the High Court (Lund, 2008).

Shifts in authority may even have effects on the form of property in question, as illustrated by Katherine Verdery's writings on post-socialist Romania (see also Sikor et al., this volume). Just as in Ghana, land was returned to its historical owners after 1990, with land restitution seen as a key project for the Romanian state to re-establish its authority on the foundation of a capitalist economy and western-style democracy. Property rights served as signifiers of the break with socialism, new political rights and participation in the economy. In addition, land restitution was crucial in reorganizing the relations between central and local units of the Romanian state. Land restitution, implemented by local land commissions, was one of the primary tasks to be undertaken by local-level institutions within a broader process of decentralization. Yet this also meant that the authority of the Romanian state, in general, and local-level institutions, in particular, was at stake in the course of land restitution. It was no surprise, then, that reports abounded in Romanian newspapers of local cases of corruption in the land restitution process. Central units of the state and other central-level actors were uneasy with the new powers enjoyed by local-level actors and contested their authority by questioning the legitimacy of their dealings (Verdery, 1996). At the same time, local-level state actors weakened the legitimacy of the Romanian state in the eyes of the local population through their corrupt practices. The actions of the mayor of a Transylvanian village discussed in Verdery (2002) impacted not only on the practice of restitution but also on the authority of the Romanian state, when he took advantage of restitution to extract bribes from claimants and carve out favours for his relatives and friends. Similarly, when villagers protested the privatization of a granary they had built under socialism, they resisted the notion of private property embedded in the legislation. They asserted a collective claim to the locally important granary on the basis of the labour they had invested in building it, countering the principles set out in national law to govern 
the privatization of socialist assets. Their claim even gained the support of a local judge, whose ruling emphasized morality and the question of what constitutes the 'public good' against the procedures specified in national legislation (Verdery, 1999).

As highlighted by Verdery's account, 'the state' is often a key politicolegal institution seeking to establish, consolidate and expand its authority by way of shopping for property claims. 'The state' may be a very important player even where property claims are hotly contested and actual power relations diffuse, as highlighted by Nuijten's research on issues of private and communal property in Mexico (Nuijten, 2003). According to Mexican law, land belonged to the ejidatarios (communal property owners), but it was effectively controlled by several private land owners. Nuijten examines the efforts undertaken by the ejidatarios to recover land that belonged to their ejido. The land conflict had lingered on for decades without resolution, in spite of numerous requests made by the ejidatarios to the Ministry of Agrarian Reform to resolve the conflict. Nevertheless, the ejidatarios went on fighting for the recovery of the land despite their general distrust of the political system and administrative bureaucracy. Nuijten explains the ejidatarios' continuing struggles with their belief in the existence of 'the state' as an imagined centre of control, which could help them to recover the 'lost land'. Their belief in 'the idea of the state' was nurtured by a series of intermediaries who pretended to have privileged relations with state officials and knowledge of state procedures. These brokers presented themselves to the ejidatarios as capable of dealing with the state bureaucracy and helping them to recover the 'lost land'. The belief in the idea of the state - and the search for its real-world personification even made the ejidatarios write to the Mexican president with a plea for support. Nuijten concludes that 'the ejidatarios are implicated in the process of the construction of the idea of the state' (2003: 118). On the other hand, their belief in the idea of the state was fostered by certain techniques of government, such as maps, documents and procedures. More broadly, one may add, their belief was rooted in the promise of the Mexican state to enforce property rights, which allegedly offered them backing for their claims to the 'lost land'. Property - or to be precise, the 'idea of property' - thus served to consolidate the authority of the Mexican state, and the competition between the ejidatarios and the private landowners over how to involve the state as an umpire had consequences for the nature of property.

Property, therefore, may be equivocal in settings characterized by uncertain relations of authority and power. Ambiguous authority attaches itself to property and renders it less than clear. Property relations may be highly uncertain when power relations are diffuse and evident concentrations of authority are absent. In such situations, property relations may not have 'crystallized into practices of exclusion and inclusion within routinized rules' (Verdery, 1999: 55). The underlying diffusion of power and authority prevent 
this (cf. Sturgeon and Sikor, 2004). This stands in contrast to conventional theories on property rights, particularly the more evolutionary approaches, which argue that as land becomes more valuable, narrower definitions of property emerge and clearer rights ensue (Demsetz, 1967; see also Firmin Sellers, 1996, 2000; Platteau, 1996). While scarcity may indeed promote exclusivity, evidence from the present collection would suggest that where there are many institutions competing for the right to authorize claims to land, the result of an effort to unify and clarify the law might well be to intensify competition amongst them and weaken their legitimacy. Thus, the 'meantime' in evolutionary theory (from an imagined situation with no property rights to an equally imagined situation with perfectly unequivocal rights) seems to characterize all societies (Rose, 1994). Nevertheless, property also attaches itself to authority in the sense that successfully defended property imbues the politico-legal institution with authority. Guaranteeing property claims offers some rewards for institutions with ambitions of authority, but this is a competitive game and does not work by mere administrative fiat.

\section{TERRITORIALITY AND VIOLENCE}

Guaranteeing property rights for some people logically means denying the same guarantee to others. As we have argued, such processes do not take place in a political vacuum: on the contrary, enforcing certain decisions about property is often met with resistance from those whose rights are eroded in the process. Understanding the processes of guaranteeing and denying property as opposed to access by other means, therefore, requires research on the political and discursive strategies operated by different politico-legal institutions. In other words, if one wants to understand how access claims become property it is necessary to examine the processes whereby authority is formed, strengthened, challenged and unravelled by way of authorizing property rights. Institutions will generally seek to legitimize their exercise of power with reference to law, or custom, precedence, or propriety, or administrative expediency. They thus seek to turn power into authority by authorizing particular property claims and by way of other strategies such as the extension of citizenship.

Institutions undertake a wide variety of activities to legitimize their authority. However, since we are concerned here with property regarding land and other natural resources, the notion of territoriality deserves particular attention. The control of spatial ordering and the control of people in space combine different techniques and policies of classification, registration and mapping (Sack, 1983; see also Walker and Peters, 2001). This not only structures the physical space, it also organizes the political perception of it. Territorializing strategies allow and disallow certain forms of land use and access; they regulate certain forms of mobility; and by differentiating 
rights to resources they contribute to the structuration of citizenship. The strategies may take the form of internal territorialization when pursued by states to establish control over natural resources and the people that use them (Vandergeest and Peluso, 1995). Following Sivaramakrishnan (1997) and Agrawal (1998), we think this evocative idea might be pushed further. It is not merely states in the form of unitary government structures that employ territorializing strategies. We suggest that generally politico-legal institutions that compete for authority in this field operate to legitimize their undertakings partly through territorial strategies. In fact, territoriality is often a key element in the exercise of authority (Lund, 2006: 693-5). By making and enforcing boundaries, by creating a turf, a quarter, a parish, a soke, a homeland etc., different socio-political institutions invoke a territorial dimension to their claim of authority and jurisdiction whereby even institutions that are not the state or do not represent formal government claim this particular attribute of governance. Territorial markers ranging from national flags through sign-boards, fences, party banners, masks and marches to graffiti on walls - or rubber trees (see Peluso, this volume) - pepper space and render it political. These markers create sometimes contiguous, but more often overlapping and frequently contradictory spaces with different structuring effects on access and property.

However, the repertoire is wide when institutions operate to enforce particular claims and hence particular ideas about property, and it does not exclude the use of physical force. Indeed, force, violence, physical presence, eviction, land grabbing, resistance, attrition, and so on, are at the base or origin of most property regimes. Violence is often an integral or underlying feature in struggles over property, sometimes preparing the ground for new legitimizing practices. Violence, force and deception are powerful instruments in establishing 'settled facts' on the ground (Peluso and Watts, 2001), and fear and risk may be as common motives for compliance as belief in power's legitimacy. Thus, when institutions attempt to sanction claims or undo rights they do not necessarily restrict themselves to peaceful means, thereby exercising their power in ways which can be considered illegitimate. Our proposition is that regardless of the origin of access and power, there is an inherent drive to legitimize the exercise of power; to launder power as authority, as it were. But there is no reason to expect that the quest for legitimacy is conducted by legitimate means alone, especially if one recognizes that what may be illegitimate to some may be seen as legitimate by others.

E.P. Thompson's classic study on the Black Act and the transformation of the forest property system in nineteenth century England shows how violence went hand in hand with legislation and the legitimation of new rights. New laws and draconian penal measures displaced common people's historical use of forest resources from the realm of tolerated customary access to the realm of illegal poaching and infringement as resources were privatized. Brute force exercised by state agents with reference to law and authority 
from the courts and government, and attacks carried out by commoners 'blacks' - with reference to customary rights and the unjust nature of new property laws marred society with violence and terror (Thompson, 1975).

The more contemporary case of conflict over land and oil revenues in Ogoniland in Nigeria, analysed by Watts (2001), is another case in point. The federal government and the petroleum companies argued that oil is the property of the state and its exploitation was granted to the companies through concession. Opposition to this reading of the property regime from the Movement of the Survival of the Ogoni People was met with extreme violence from the military. Violent intimidation of the inhabitants and their spokespersons has been intense since the early 1990s. Controversy over how best to voice the interests of the Ogoni community - their property claims vis-à-vis the state and the oil companies - has also resulted in violence between Ogoni and neighbouring communities as well as internecine violence amongst the Ogonis themselves. This example is complicated - though not uncommon - in the sense that state institutions operated both as stakeholders claiming property rights $v i s-\grave{a}$-vis the local people and as the authorizing institutions deciding on the issue. The opportunities for rent seeking by state officials under such circumstances are gigantic, and the instrumentalization of state power to secure property to the powerful is classical.

A final brief example is the violent evictions of smallholders from the communal areas in Vumba, Zimbabwe in the late 1990s, analysed by Hammar (2002). The evictions actually concerned many more than those for whom the government had managed to produce summons and eviction orders. Again, the violence could be seen as the state's exercise of means of last resort - hence it was legitimate action from the perspective of some. From the perspective of others, however, the state's resort to legal procedures was a cover for massive evictions and a ploy to instil fear in anybody who might have contemplated opposition. The more recent violent seizures of large farms by 'war veterans' in Zimbabwe would appear also to be condoned by government and its supporters, although they have little basis in law (see also Peluso, this volume). We put these examples forward because they demonstrate the double nature of violence and law. While government institutions may resort to violence as an ultimate means of power, such violence is not necessarily legitimized successfully in the eyes of all subjects. There are many examples of violence considered illegitimate; even if efforts to justify state violence claim the opposite. Also, violence may well be exercised by other groups in concert or collusion with government agents, or in opposition to them. As argued above, it makes little sense for us to determine what is legitimate and what is illegitimate violence in absolute terms; our analytical interest lies with how politico-legal institutions may employ violent means in their quest for legitimacy. The occurrence of violence does not diminish the need to look at institutions' quest for legitimacy if one wants to understand the dynamics of property. 


\section{THE CONTRIBUTIONS TO THIS VOLUME}

The contributions to this volume demonstrate the validity of thinking in terms of access and property, on the one hand, and power and authority, on the other. Moreover, they indicate how property and access to natural resources are intimately bound up with the exercise of power and authority. At the same time, each contribution emphasizes a slightly different aspect of the conjoined processes of authorizing property claims and legitimizing politico-legal institutions.

Sara Berry examines how negotiations over property rights to land intersect with those of social belonging, and how both types of negotiations are part of broader processes constituting authority at local and national levels. Looking at competing land claims in West African localities, she compares case histories of land acquisition and use, connecting local competition over land with national-level politics in Ghana, Côte d'Ivoire and Benin. Land claims, she finds, have been linked historically to claims on authority and social belonging at the local level. At the same time, local contestations over land, social belonging and authority have resonated with claims to citizenship and electoral politics at the national level. As a result, recent neoliberal efforts to privatize land or clarify ownership have intensified debates over citizenship and authority across West Africa, provoking rather than alleviating political conflict.

The intersection of negotiations over property with social identities is also a key theme in Nancy Peluso's analysis of landscape dynamics in West Kalimantan, Indonesia. Peluso examines how the Indonesian state has shaped contestations over property rights to land and the construction of ethnic identities. The Indonesian state emerging from her analysis is much more powerful than the West African states in Berry's account. The colonial state effectively shaped ethnic identities, thereby producing not only Dayak and Chinese but also 'racialized territorialities', that is, territorialities associated with and productive of ethnic identities. Years later, the independent state employs violence to effectively erase prior identity-based claims of the Chinese and to establish the control of new actors over trees, land and legitimate access or rightfulness. Peluso thus makes the important point that violence plays a significant role in eliminating earlier rights, levelling the ground for establishing a new set of property rights and associated legitimations.

Monique Nuijten and David Lorenzo look at the 'performance of authority' in a Peruvian comunidad campesina. Their analysis of land administration in the comunidad reveals how control over land is enacted and helps to constitute local authority relations. Both leaders and regular members display strong concern with the rules governing the registration and reallocation of agricultural land. The enactment of the rules in the yearly reallocation procedure constitutes a key pillar of the authority attributed to the comunidad campesina. There is a glaring gap between the rules that people rehearse in 
meetings and actual practice in land reallocation and administration. This observation leads Nuijten and Lorenzo to conclude that talk about rules, or 'rule talk', plays an important role in the performance of authority in the comunidad, highlighting the significance of legitimizing practices in the constitution of authority.

Jesse Ribot's contribution shares the focus on practices legitimizing authority with Nuijten and Lorenzo. Ribot analyses struggles over authority between two different units of the state in relation to competing claims on forests in rural Senegal. Local people and merchants compete with each other over the distribution of benefits derived from the wood cut in local forests for the production of charcoal, seeking authorization for their claims from the Forest Service and Rural Councils. Decentralization has shifted statutory control over forests from the former to the latter, ostensibly giving the elected councils significant powers. Yet decentralization has not conferred effective control over forest to local governments, as the Forest Service continues to control the exploitation of forests and urban-based merchants maintain their lucrative access to forests. Ribot concludes that local governments are unlikely to gain legitimacy in the eyes of the population as long as they cannot effectively back up their constituents' claims to forest resources.

Christian Lund examines how land resources have been recategorized between the two 'master categories' of public and private in the course of political struggle in northern Ghana. Despite the fact that such master categories may be wholly inadequate in accounting for the actual complexity of property objects, social units and rights, people with something at stake use them actively and bring them into effect. Laws, rules and by-laws are referred to as important markers and fashion the local political struggles over the rights to and control over resources. Lund offers a general account of conflicts and the recategorization of resources in the property system of small-scale irrigation. Here, the logics of the different stakeholders and their positioning is examined, and how different levels of public policy have provided opportunities for such changes is discussed. The chapter also examines the details of a particular controversy demonstrating the social and political powers involved in the recategorization of property.

Rikke Broegaard shifts the analytical lens away from the primary focus on authority in the previous chapters towards the process of authorizing claims to resources as property. Her account of a land registration and land titling programme in rural Nicaragua examines how social actors are differently positioned to gain state endorsement of their land claims as property rights. Land registration and titling do not benefit all people equally; less fortunate households do not register land, and it is mainly the more powerful who obtain land titles. People's ability to get their claims to land recognized depends on their capacity to call upon the state officials involved. Of particular significance are 'local kings' - powerful state officials who 
take advantage of their position to issue titles to their affiliates in direct contradiction with the law. The local kings also use their leverage on land administration to acquire land titles for themselves. Like Berry, Broegaard thus finds that neoliberal programmes seeking to privatize land or clarify land ownership may aggravate contestations over authority and cause political conflicts.

Thomas Sikor, Johannes Stahl and Stefan Dorondel also focus on local negotiations over access and property. Like Broegaard, they look at negotiations taking place in the context of large-scale land reform programmes, in this case post-socialist land reforms in Albania and Romania. In addition, they examine how local struggles over forests in four localities are conditioned by and feed into national-level politics. There are distinct differences between the Albanian and Romanian cases, particularly in the ways in which local struggles shape the authority attributed to the state. These differences reflect the influence of national politics on local struggles and simultaneously indicate how post-socialist politics have come to follow different trajectories in the two countries. The emergence of customary arrangements challenges the Albanian state as the primary politico-legal institution of authority. In Romania, contestations over authority do not challenge the state as an institution but pitch more personalized forms of exercising authority against those that are more closely governed by law.

Dik Roth finally returns to the primary concern with contestations over authority which are found in the contributions of Nuijten and Lorenzo and Ribot. Roth examines contestations over authority between two kinds of irrigation institutions in a migrant society in Sulawesi, Indonesia. One institution, the water users' association, was established and backed by the Indonesian state. The other institution, the 'traditional' subak, was introduced by Balinese migrants. Each institution defines the bundles of rights and responsibilities pertaining to management in a different way, and hence endorses a different set of land and water management norms, rules and practices. The differences cause direct conflict between local state representatives and Balinese irrigators over the scope and degree of legitimacy attributed to these institutions. Yet they also lead irrigators to adjust the rules of both institutions in order to reduce conflict, in the process transforming both the water users' association and the subak into completely unique and localized institutions.

\section{BY WAY OF CONCLUSION}

Property and access are not predefined categories, but distinctions between property and access are linked to the formation, consolidation, expansion, contestation, contraction and decline of authority. In this essay we have sketched out a complex of relationships between access and property and between power and authority in order to suggest the importance of making 
the distinctions, identifying the connections and recognizing the recursive constitutions between them. Struggles over property are as much about the scope and constitution of authority as they are about access to resources. Similarly, contestations over authority deal as much with the nature and distribution of property as with issues of power.

The relationships between access and property and between power and authority are dynamic. While individuals and institutions may harbour ambitions of a particular development from access to consolidated property, and from power to legitimate authority, we propose that this is an inherently empirical question. The actual trajectory rarely confirms a simple, predictable evolutionary direction. Just as many people struggle to turn access claims into legitimate property, many are stripped of property rights to their possessions when the institutions that guaranteed them are weakened. Similarly, just as competing institutions attempt to shore up legitimacy for their power, that legitimacy may well be undermined by circumstances in the wider fabric of society beyond their control. Institutional opportunities and strategies are almost as plentiful as historical circumstances, but we suggest that in the attempt to understand the relations between struggles over natural resources, contestations about authority and state formation, attention to legitimizing strategies will be rewarded.

We finally argue that it is useful to think in terms of the concepts of access and property on the one hand and power and authority on the other for another important reason: they offer an analytical perspective on the politics and governance of resources where categories do not define our focus. Rather, attention to the recursive constitution of access and property on the one hand and power and authority on the other help to make the socio-political processes of categorization the object of investigation (see Lund, this volume). The grey zones between access and property and power and authority are exactly where categorization takes place. This categorization is, we argue, part of a state formation process made up by competing institutions' quest for authority in different significant domains.

\section{REFERENCES}

Agrawal, A. (1998) Greener Pastures: Politics, Market, and Community among a Migrant Pastoral People. Durham, NC and London: Duke University Press.

Agrawal, A. (2005) Environmentality: Technologies of Government and the Making of Subjects. Durham, NC and London: Duke University Press.

von Benda-Beckmann, F. (1995) 'Anthropological Approaches to Property Law and Economics', European Journal of Law and Economics 2: 309-36.

von Benda-Beckmann, F. and K. von Benda-Beckmann (1999) 'A Functional Analysis of Property Rights, with Special Reference to Indonesia', in T. van Meijl and F. von BendaBeckmann (eds) Property Rights and Economic Development: Land and Natural Resources in Southeast Asia and Oceania, pp. 15-56. London and New York: Kegan Paul International. von Benda-Beckmann, F., K. von Benda-Beckmann and M. Wiber (2006) 'The Properties of Property', in F. von Benda-Beckmann, K. von Benda-Beckmann and M. Wiber (eds) Changing Properties of Property, pp. 1-39. New York: Berghahn. 
von Benda-Beckmann, K. (1981) 'Forum Shopping and Shopping Forums: Dispute Processing in a Minangkabau Village in West Sumatra', Journal of Legal Pluralism 19: 117-59.

Berry, S. (1993) No Condition is Permanent: The Social Dynamics of Agrarian Change in Sub-Saharan Africa. Madison, WI: University of Wisconsin Press.

Berry, S. (2002) 'Debating the Land Question in Africa', Comparative Studies in Society and History 44(4): 636-68.

Boone, C. (2003) Political Topographies of the African State: Territorial Authority and Institutional Choice. New York: Cambridge University Press.

Cleaver, F. (2002) 'Reinventing Institutions: Bricolage and the Social Embeddedness of Natural Resource Management', European Journal of Development Research 14(2): 11-30.

Comaroff, J.L. and J. Comaroff (eds) (1999) Civil Society and the Political Imagination in Africa. Chicago, IL: University of Chicago Press.

Corbridge, S., M. Srivastava and R. Veron (2005) Seeing the State: Governance and Governmentality in India. Cambridge: Cambridge University Press.

Cousins, B. (1997) 'How Do Rights Become Real? Formal and Informal Institutions in South Africa's Land Reform', IDS Bulletin 28(4): 59-68.

Das, V. and D. Poole (eds) (2004) Anthropology at the Margins of the State. Santa Fe, NM: School of American Research Press.

Demsetz, H. (1967) ‘Toward a Theory of Property Rights', American Economic Review 57(2): 347-59.

Douglas, M. (1986) How Institutions Think. Syracuse, NY: Syracuse University Press.

Ferguson, J. and A. Gupta (2002) 'Spatializing States: Toward an Ethnography of Neoliberal Governmentality', American Ethnologist 29(4): 981-1002.

Firmin-Sellers, K. (1996) The Transformation of Property Rights in the Gold Coast. Cambridge: Cambridge University Press.

Firmin-Sellers, K. (2000) 'Custom, Capitalism, and the State: The Origins of Insecure Land Tenure in West Africa', Journal of Theoretical and Institutional Economics 156: 513-30.

Fortmann, L. (1995) 'Talking Claims: Discursive Strategies in Contesting Property', World Development 23(6): 1053-63.

Foucault, M. (1980) 'Truth and Power', in C. Gordon (ed.) Power/Knowledge, pp. 109-33. New York and London: Harvester Wheatsheaf.

Gupta, A. and J. Ferguson (eds) (1997) Culture, Power, Place: Explorations in Critical Anthropology. Durham, NC: Duke University Press.

Hammar, A. (2002) 'The Articulation of the Modes of Belonging: Competing Land Claims in Zimbabwe's Northwest', in K. Juul and C. Lund (eds) Negotiating Property in Africa, pp. 211-46. Portsmouth, NH: Heinemann.

Hansen, T.B. and F. Stepputat (eds) (2001) States of Imagination: Ethnographic Explorations of the Postcolonial State. Durham, NC: Duke University Press.

Hansen, T.B. and F. Stepputat (eds) (2005) Sovereign Bodies: Citizens, Migrants and States in the Postcolonial World. Princeton, NJ and Oxford: Princeton University Press.

Juul, K. and C. Lund (eds) (2002) Negotiating Property in Africa. Portsmouth, NH: Heinemann.

Leach, M., R. Mearns and I. Scoones (1999) 'Environmental Entitlements: Dynamics and Institutions in Community-Based Natural Resource Management', World Development 27(2): 225-47.

Lentz, C. (1998) 'The Chief, the Mine Captain and the Politician: Legitimating Power in Northern Ghana', Africa 68(1): 46-65.

Li, T.M. (2007) The Will to Improve: Governmentality, Development, and the Practice of Politics. Durham, NC: Duke University Press.

Lund, C. (2002) 'Negotiating Property Institutions: On the Symbiosis of Property and Authority in Africa', in K. Juul and C. Lund (eds) Negotiating Property in Africa, pp. 11-43. Portsmouth, NH: Heinemann.

Lund, C. (2006) 'Twilight Institutions. Public Authority and Local Politics in Africa', Development and Change 37(4): 685-705. 
Lund, C. (ed.) (2007) Twilight Institutions: Public Authority and Local Politics in Africa. Oxford: Blackwell.

Lund, C. (2008) Local Politics and the Dynamics of Property in Africa. Cambridge and New York: Cambridge University Press.

MacPherson, C.B. (1978) 'Introduction', in C.B. MacPherson (ed.) Property: Mainstream and Critical Positions, pp. 1-13. Toronto: University of Toronto Press.

Migdal, J. (2001) State in Society: Studying How States and Societies Transform and Constitute One Another. Cambridge: Cambridge University Press.

Moore, D. (2005) Suffering for Territory: Race, Place, and Power in Zimbabwe. Durham, NC and London: Duke University Press.

Moore, S.F. (1988) 'Legitimation as a Process: The Expansion of Government and Party in Tanzania', in R. Cohen and J.D. Toland (eds) State Formation and Political Legitimacy, pp. 155-72. New Brunswick, NJ: Transaction Books.

Moore, S.F. (1992) 'Treating Law as Knowledge. Telling Colonial Officers What To Say to Africans about Running “Their Own” Native Courts', Law \& Society Review 26(1): 11-46.

Moore, S.F. (1998) 'Changing African Land Tenure Reflections on the Incapacities of the State', European Journal of Development Research 10(2): 33-49.

Nuijten, M. (2003) Power, Community and the State: The Political Anthropology of Organisation in Mexico. London and Sterling, VA: Pluto Press.

Peluso, N. (1992) Rich Forests, Poor People: Resource Control and Resistance in Java. Berkeley, CA: University of California Press.

Peluso, N. and M. Watts (2001) 'Violent Environments', in N. Peluso and M. Watts (eds) Violent Environments, pp. 3-38. Ithaca, NY and London: Cornell University Press.

Peters, P. (2004) 'Inequality and Social Conflict over Land in Africa', Journal of Agrarian Change 4(3): 269-314.

Platteau, J.-P. (1996) 'The Evolutionary Theory of Land Rights as Applied to Sub-Saharan Africa: A Critical Assessment', Development and Change 27(1): 29-86.

Ribot, J. (1998) 'Theorizing Access: Forest Profits along Senegal's Charcoal Commodity Chain', Development and Change 29(2): 307-41.

Ribot, J. and N. Peluso (2003) 'A Theory of Access', Rural Sociology 68(2): 153-81.

Rocheleau, D. and L. Ross (1995) 'Trees as Tools, Trees as Text: Struggles over Resources in Zambrana-Chacuey, Dominican Republic', Antipode 27(4): 407-28.

Rose, C. (1994) Property and Persuasion: Essays on the History, Theory, and Rhetoric of Ownership. Boulder, CO: Westview Press.

Sack, R.D. (1983) Human Territoriality: Its Theory and History. Cambridge: Cambridge University Press.

Shipton, P. and M. Goheen (1992) 'Understanding African Land-Holding: Power, Wealth, and Meaning', Africa 62(3): 307-25.

Sikor, T. and Q.T. Nguyen (2007) 'Why May Forest Devolution Not Benefit the Rural Poor? Forest Entitlements in Vietnam's Central Highlands', World Development 35(11): 2010-25.

Sivaramakrishnan, K. (1997) 'A Limited Forest Conservancy in Southwest Bengal, 1864-1912', Journal of Asian Studies 56(1): 75-112.

Sivaramakrishnan, K. (1999) Modern Forests: Statemaking and Environmental Change in Colonial Eastern India. Stanford, CA: Stanford University Press.

Steinmetz, G. (ed.) (1999) State/Culture: State Formation after the Cultural Turn. Ithaca, NY: Cornell University Press.

Sturgeon, J. (2005) Border Landscapes: The Politics of Akha Land Use in China and Thailand. Seattle, WA and London: University of Washington Press.

Sturgeon, J. and T. Sikor (2004) 'Post-Socialist Property in Asia and Europe: Variations on "Fuzziness", Conservation and Society 2(1): 1-17.

Thompson, E.P. (1975) Whigs and Hunters. New York: Pantheon Books.

Tilly, C. (1985) 'War Making and State Making as Organized Crime', in P. Evans, D. Rueschemeyer and T. Skocpol (eds) Bringing the State Back In, pp. 169-91. Cambridge: Cambridge University Press. 
Vandergeest, P. and N. Peluso (1995) 'Territorialization and State Power in Thailand', Theory and Society 24: 385-426.

Verdery, K. (1996) What Was Socialism? And What Comes Next? Princeton, NJ: Princeton University Press.

Verdery, K. (1999) 'Fuzzy Property: Rights, Power, and Identity in Transylvania's Decollectivization', in M. Burawoy and K. Verdery (eds) Uncertain Transition: Ethnographies of Change in the Postsocialist World, pp. 53-81. Lanham, MD: Rowman \& Littlefield.

Verdery, K. (2002) 'Seeing Like a Mayor. Or, How Local Officials Obstructed Romanian Land Restitution', Ethnography 3(1): 5-33.

Verdery, K. (2003) The Vanishing Hectare: Property and Value in Postsocialist Transylvania. Ithaca, NY: Cornell University Press.

Walker, P.A. and P. Peters (2001) 'Maps, Metaphors and Meanings: Boundary Struggles and Village Forest Use on Private and State Land in Malawi', Society and Natural Resources 14: 411-24.

Watts, M. (2001) 'Petro-Violence: Community, Extraction, and Political Ecology of a Mythic Commodity', in N. Peluso and M. Watts (eds) Violent Environments, pp. 189-213. Ithaca, NY and London: Cornell University Press.

Weber, M. (1976) [1922] Wirtschaft und Gesellschaft: Grundriss der Verstehenden Soziologie (Economy and Society: An Outline of Interpretive Sociology). Tübingen: J.C.B. Mohr. 